Сања Париповић Крчмар

Филозофски факултет Универзитета у Новом Саду
УДК 821.163.41.09 Теšić M.

Оригиналан научни рад

\title{
ТРИОЛЕТИ МИЛОСАВА ТЕШИЋА
}

У раду се анализују песме Милосава Тешића написане у облику триолета из збирке Прелесии севера, Круі рачански, Дунавом и Бубњалица у йчелињаку у односу на традицијом утврђену норму сталног облика и невелику групу триолета написаних у српској књижевности 19. века. Његова скупина триолета није пример давнашње теоријске рефлексије о лаком, допадљивом, шаљивом садржају, већ, пре свега, саображености поетичком начелу. Ове песме чине једну компактну групу вишеструко компатибилну: тематски, обликовно, метрички, ритмички, римовно, синтаксичком организацијом, што све скупа, песнику усложњава задатак успешне реализације сталног облика ионако захтевних композиционих правила.

Кључне речи: рачански круг, стални облици, триолети, јампски стих, евокација, рефренски иктуси

Признање да је задати облик за песника истински изазован ${ }^{1}$ разоткрива вредносне координате Милосава Тешића и потврђује његово поимање важности књижевне традиције. Управо у чињеници да се стабилни облици у актуелним модернистичким струјањима могу сматрати превазиђеним и немодерним, легитимно је песниково посезање за оним што је непропадљиво и истински вредно. ${ }^{2}$ Доследан континуираној потреби уградње мишљења у традиционалне обрасце и повлашћене позиције опсервирања „непотрошене обличке енергије“ усмерене ка продуктивном оживљавању мноштва пореклом различитих сталних облика ${ }^{3}$, готово подвижнички и апартно свим својим поетским књигама Тешић је богатио формално пространство, доприносећи, како је и сам констатовао, потврди бића и виталности поезије. ${ }^{4}$

sania0205@yahoo.com

О Тешићевом односу према везаном и слободном стиху, нормираним формама и њиховој мултифункционалности, видети у есеју „О устаљеним лирским облицима“ (2004: 209-211) и у разговору „Задати облик као изазов“ (1992: 711-717).

2 Однос према књижевном наслеђу Тешић заснива „на схватању да је традиција у књижевности првенствено оно што је естетски вредно у њој, што је њено живо, нетрулежно ткиво“ (1995: 215).

3 Романски облици: сонет, сонетни венац, рондо, балада, балата, рондел, лауда, триолет, глоса, терцина. Грчко-византијски облици: канон, кондак, стихира, светилан, псалм.

4 О Тешићевој примени сталних облика, стиховном репертоару и аутопоетичким промишљањима видети Париповић Крчмар 2015. 
Својом четвртом песничком збирком Прелесӣ севера (1995) Милосав Тешић је оживео тематско-мотивски лирску хроничарску димензију о сеобном кретању српског народа и рачанских монаха из јужних крајева дринског подручја пут Паноније. Овај иницијални замах рачанске компоненте постиже свој целовити распон накалемљеним другим делом Круі рачански, Дунавом, касније обједињен у „нову песничку крошњу“ (Гордић, 1998: 159) Прелесй севера, Круі рачански, Дунавом (1996). Перспективи условљеној другачијом традицијом и културом парира и другачији репертоар облика. Перципирање промене матичног животног простора ингениозно је интензивирано спектром нових форми (балада, рондел, триолети, балата, лауда, уз већ испробане могућности ронда). Оно што овај придодати други део на Прелесй севера издваја од дотадашњег Тешићевог сувереног опхођења према облику фундирано је на проблему укрштаја и ефекту онеобичавања. Наиме, посезање за реквизитима романског наслеђа не проноси и њихову подразумевану семантику стечену у изворној традицији, како је то примећено у литератури, већ износи, идејом амалгамисања, замисао одрживости

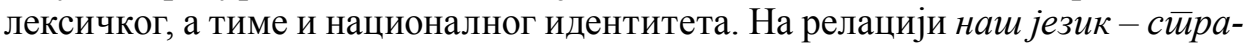
на форма, односно сииаро, зайамћено, ненайушиено - ново, ииуђе, усвојено, на којој почива неминовност концепта прогонства, Тешић гради свој рачански круг или поетски костимирано - „теготу своју увија у рондел““5. „Као да се сам језик труди да ублажи тугу, мимикријом с новим формама се бранећи од болне идентификације са старим парним стихом јуначких песама“, закључује Саша Радојчић у раду о дунавском триптиху (1998: 206).

Свим поменутим облицима писано је у српској књижевности 20. века, изузев триолета које управо Тешић обнавља. Прва примена овог осмостиха са две риме везује се за име Александра Андрића, иза кога су остале објављене две песме 1841. и 1843. године, а пар година касније забележена је и прва дефиниција триолета у српској књижевности из пера Јована Суботића (1845). У 19. веку идентификовано је 15 триолета, у књижевној периодици и песничким збиркама, чији су аутори већином анонимни. ${ }^{6}$ У намери да не остану део наше заборављене традиције, у времену одбацивања традиционалних вредности, песник се прикључује групи ствараоца триолета објављујући их чак осам у збирци Прелесіи севера, Круі рачански, Дунавом:

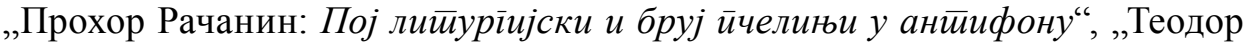
Рачанин: У вия иризван иооилеg с Повлена, а у слух чекей мойке за иирешење шљьива“, „Кипријан Рачанин: Листиак буквара“, „Христофор Рачанин: Жижак йсалимира“, „Григорије Рачанин: Панонијом с крстиом рачанским I-III“ и „Симеон Рачанин: Kag с клисе махну орлови“. Ову скупину триолета од већине до тада објављених дистингвира, као што је речено, пре свега са-

Стих песме „Висарион Рачанин: Рачом о иоосйу часном“.

О триолетима у српској књижевности видети Грдинић 1991: 96-108. Једини студиозни рад о овом сталном облику употпуњен је и додатком у виду збирке свих пронађених триолета наших аутора, са подацима где су објављени и у којим су књигама узимани у својству примера. 
ображеност поетичком начелу, сасвим опозитно некадашњој примени у виду досетке, игре, ради забаве. Тешићеве песме у овом облику нису пример давнашње теоријске рефлексије о лаком, допадљивом, шаљивом садржају; у њима се евоцирају просторне завичајне слике од којих су рачански монаси отргнути, потом ослушкују звучне нафоре - литургијски пој, бруј пчелињи, чекет мотке, да сточен жал и бол прогонством условљени не умину.

\section{Прохор Рачанин:}

\section{Пој литиуріицски и бруј йчелињи у анйифону}

Оgбруји йојак ракитиом -

сииихиу иччеле сайворе.

У чедност сточив антифон, оябруји йојак ракийом.

Затрепте душе шалитром

са стручка звучне нафоре.

Оябруји иоојак ракитиом-

сиихиру иччеле сайворе.

\section{Теодор Рачанин:}

У вия иризван йойлеg с Повлена, а у слух чекей мойке за иррешење шиьива

У йоїлеg иризван с Повлена

ирокайљи родом, јесени:

да жал ми сукне с корена

у йоіле еиризван с Повлена;

да чекет мотке опсена

у шљивов тамјан стресе ми.

У йоілеg иризван с Повлена

ирокайљи рояом, јесени. ${ }^{8}$

Имајући у виду заједничку карактеристику групе облика којој припадају триолети, а то је заснованост на „,raznovrsnim doslovnim ili djelomičnim ponavljanjima stihova, na višestrukom ponavljanju pojedinih rima ili početnih i zadnjih riječi u stihu, i sl.“ (Petrović, 1983: 404), јасно је да се репетицијом, односно таутолошким паралелизмом, постиже незаборављање, похрањивање у меморији слика некадашњег живота. Сваки рефренски стих целокупног

Видети Андрић 1863. и Малетић 1869.

Може се претпоставити да се из ових песничких слика у потоњем времену изродила антологијска песма „Шљива српска“ као Тешићев заштитни знак, међу многим таквим песмама. Варијантом синтагме „шљивов тамјан“ гради се иницијални стих последње строфе шљиве - а срйске - „Дремај, тежино тамјана модрог:““. 
корпуса сталних облика Круїа рачанскої, Дунавом у функцији је призивања онога у чему се некада егзистирало, што је некада била монашка свакодневица; примера ради:

По лудом йољу иожар је, и крв је.

По церов-їорjу ìgeìge врана, їачак,

У иркви лийе лийов бої се светили,

Шљивике іужва рачвасти налей ветира.

У йоїлеg иризван с Повлена

ирокайљи родом, јесени:

О сийка звезяо с Тариної їаја,

У словну славу јасниие се, фруле.
(„Рачанска балада“)

(рондел „Висарион Рачанин:

Рачом о йосӣу часном")

(рондо „Прохор Рачанин: Лийа рачанска")

(рондо „Киријак Рачанин:

Сан у исйосници")

(триолет)

(рондо „Јеротеј Рачанин:

Поноћни освити

'Пуйашестивија"“)

(лауда „Стефан рачанин: $V$ словну славу“)

Управо ће ту чињеницу аутопоетички, метаметрички и графички песник сажети у рефренима једног од триолета, јер су све песме у поменутим облицима испеване јампским стиховима (једанаестерац, симетрични десетерац и асиметрични осмерац), а курзивом нотирани рефренски стихови - иктуси ${ }^{9}$ јесу у кључној, ударној позицији, односно носиоци су главне идеје.

\section{Кипријан Рачанин: Лисйак буквара}

У ритиму јамйскої уgара

курзивом звецну икйуси.

Зашуми листак буквара

у рийму јамйскої удара.

Узлети, птицо, с угара

да живну жубор-импулси.

У ритиму јамйскої удара

курзивом звецну икйуси.

Тематско одређење у првим стиховима тако ће се у свих осам триолета доследно варирати „увођењем подређених мотива дајући тако рефренима нове нијансе у значењу након сваког понављања" (Грдинић, 1991: 99). Овакав

\footnotetext{
9 У версификацијској терминологији јако време стиха, места на којима очекујемо нагласак.
} 
начин развијања теме доминантан је био у готово свим објављеним триолетима, констатује Никола Грдинић, што казује да Тешић наставља традицију одабраног унутрашњег компоновања. ${ }^{10}$

Доследно се поштују композициона правила оформљена у француској средњовековној књижевности - осам стихова римована ABaAabAB ${ }^{11}$. У контексту рачанског круга, можда није занемарљива бројчана еквивалентност и песама, и стихова у песми и изабраног метра. Интензивну спону са традицијом и нормираним моделом песник постиже управо метричким обрасцем, дисциплиновано испевајући све песме јединственом структуром јампског осмерца, строго поштујући правило не померања акцента на слабо време стиха. Тако се и овај метар прикључује строгим силабичко-тонским стиховима раније примењиваним, попут јампског једанаестерца. ${ }^{12}$ Наиме, складно се без иједног одступања нижу амфибрах, трохеј и дактил, кроз сва 64 стиха; тако се коректно сваки од њих сегментира на $3+2+3$. Уз остале краће стихове (трохејски осмерац, седмерац и шестерац), јампски осмерац уобичајен је у триолетима књижевности других европских земаља. У свим Тешићевим триолетима метричка константа је наглашеност парних слогова, са особеном „празном стопом“ на крају стиха ${ }^{13}$, односно и претпоследњим ненаглашеним слогом оствареним дактилском стопом. Овакав перфекционизам у организацији ритма и доследност у поштовању метричких правила нису за нас изненађење када говоримо о целокупном песништву Милосава Тешића. Одабрани метар песник је прецизно поштовао и у другим облицима, и у другим збиркама. Примера ради, у посебној врсти сонета коју назива сонетима продуженог трајања, не одступа од симетричног четрнаестосложног стиха; или, пак, у канонима које гради шестостопним дактило-трохејским петнаестерцем. Повиновање строжој организацији могло је створити утисак претеране и непотребне укалупљености израза, немогућност досезања потпуног семантичког ефекта, шта више, и ритмичку монотонију узроковану предвидљивошћу, међутим, таква ритмичка таутологија у триолетима интензификатор је основног поступка евокације. Из монашке тренутне перспективе сва некадашња животна емпирија преводи се у вербалну материју, у песму, како би се сачувала од усуда заборава. Она друга стварност, дакле, опстаје само сећањем, реконструкцијом момената очуваног лелујавог лика. „Због тога се и може рећи“, закључује Радивоје Микић, „да

10 Друга могућност је „да довођењем рефрена у другачији контекст постигну неочекиване обрте, чиме се триолет по начину остваривања семантичких ефеката приближава епиграму“ (1991: 99).

11 Када је реч о рими треба подсетити на речи Никше Стипчевића у вези са песмама збирке Прелесй севера, Круї рачански, Дунавом: „Тешићеве речи које држе риму вазда су у тесној вези са смисаоним језгром стиха, а речи које се римују једна другој допуњују значење и затварају један смисаони круг. [...] Тешић прилично вешто користи сложену риму, ону коју италијански версолози називају - rima franta: бол ми је - бор ми је; зараgуј ме - чуј ме; Тиса ми - сиисса ми“ (1998: 16). Први и трећи пример овакве риме издвојени су управо из триолета.

12 О стиху Милосава Тешића видети рад Леона Којена „Метар и традиција“ 1998: 111-141, или 2012: 129-168, где је објављен и Додатак овога рада (169-176).

13 Како је Којен назива. 
је Милосав Тешић песник симболистичке оријентације, да је он песник који верује да се у поезији ствара реалност која се онтологизује кроз звук, мелодију и симболички наговештај. И тако постаје такмац оној реалности кују перципирамо као емпиријску““ (1998: 55).

И овим својством, иако нису циклично повезане, песме у триолетима унутар поменутог дела уцеловљене песничке књиге остварују кореспондентност и чине једну компактну групу вишеструко компатибилну: тематски, обликовно, метрички, ритмички, римовно, синтаксичком организацијом ${ }^{14}$, што све скупа, песнику усложњава задатак успешне реализације сталног облика ионако захтевних композиционих правила. Мада, таква правила „строга и са пуно ограничења, пре него даровитост захтевала су велики труд и вештину, па је стога триолет био привлачан за неталентоване песнике“, бележи Грдинић у свом раду о присуству овог осмостиха са две риме у српској књижевности, указујући, потом, да је писање ове фиксне форме увек „на деликатној граници између песничке тривијалности и уметничке поезије дискретног шарма“" (1991: 103). Међу ауторима који су својим триолетима постигли дозу шарма, па и „опажљив песнички домет“, попут аутора са псеудонимом Звездан, затим Јована Драгашевића и Александра Андрића, наводи се и име Милосава Тешића (Грдинић, 2007: 168). Имајући у виду да Тешић наставља поетичка усмерења српских неосимболиста, те да му се из аспекта обнављања сталних облика, што је једна од битних одлика ове групе песника, може утиснути неосимболистички поетолошки предзнак, анулира се чињеница да је триолет похрањен у заборав; шта више, њиме се и допуњује ионако богат репертоар облика који су песници модернизоване традиције обновили и увели у српску књижевност.

Овим обликом Тешић поново пева у збирци Бубњалица у йчелиња$\kappa y$ (2001), објединивши песме истим насловом „Два триолета за Банију“. Остаје доследан свим пропозицијама утврђеним у осам претходних песама, међутим, са наглашенијим присуством песниковог става о друштвеној стварности („Ненарод, или светина, / зар то си, роде, с Баније!?“) и тренуцима политичких малверзација (,Тек узвик ЈАО збира се / у кликер-игру држава.“). Уз негодовање осетна је и опомена неуминућа обележја националног идентитета и очувања реликвија, како у нареченом крсту рачанском (читали смо у доживљају путање као крстаче Григорија Рачанина - „У АЗ ме, стазо, завеји“), тако и поентираним рефренским стиховима другог триолета императивно интонираним призивањем божанског присуства - „Поїле́gни, Боже, низа се / у йрийиих Саве Мркаља“".

14 Готово свака песма синтаксички је дистишно организована, чине је четири реченице. 
Sanja Paripović Krčmar

\section{MILOSAV TEŠIĆ'S TRIOLETS}

\section{SUMMARY}

Milosav Tešić has revived the triolet form in the age known for the rejection of traditional values by composing eight triolet poems in the volumes of poetry Prelest severa, Krug račanski, Dunavom and two more such poems in the collection Bubnjalica u pcelinjaku. He respects the traditional format of this fixed form, thus expanding the limited group of triolets written in the 19 th century Serbian literature. His triolet collection is not in accord with former reflections on this form as having light and likable, humorous content, but rather, first and foremost, strives to obey the principle of formal artistry. These poems comprise a compact and highly compatible group in view of the subject, format, metric, rhythmic, rhyme and syntax structure. All these elements closely knit together impose new tasks on the poet's mission of a successful realization of this fixed form, already known for its demanding rules of composition.

Key words: Racha circule, fixed forms, triolets, iambic verse, evocation, chorus ictus 


\section{ЛИТЕРАТУРА}

Андрић, А. (1863). Закони стихотворства, предговор. Сииихойворенија. Београд, I-XIII. Гордић, С. (1998). Нови лирски кругови Милосава Тешића. У: Јовановић, А., Хамовић, Д. (уред.) (1998). Милосав Тешић, иесник, зборник радова. Краљево: Народна библиотека „Стефан Првовенчани“, 155-162.

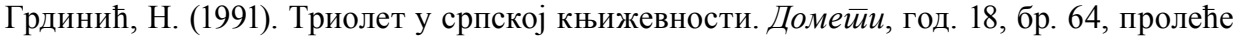
1991, 96-108.

Грдинић, Н. (2007). Сйални облици иеесме и сйрофе. Београд: Народна књига - Алфа.

Којен, Л. (1998). Метар и традиција. У: Јовановић, А., Хамовић, Д. (уред.) (1998). Милосав Тешић, иесник, зборник радова. Краљево: Народна библиотека „Стефан Првовенчани“, 111-141.

Којен, Л. (2012). Метар и традиција. Додатак. Оїлеgи о йоезији. Београд: Чигоја штампа, 129-168; 169-176.

Малетић, Ђ. (1869). Теорија йоезије. Београд.

Микић, Р. (1998). Милосав Тешић као симболиста. У: Јовановић, А., Хамовић, Д. (уред.) (1998). Милосав Тешић, иесник, зборник радова. Краљево: Народна библиотека „Стефан Првовенчани“, 33-56.

Париповић Крчмар, С. (2015). Формариј Милосава Тешића. У: Звук, мейар и смисао Милосава Тешића, зборник радова. Београд - Требиње: Институт за књижевност и уметност - Општина Требиње (зборник у припреми).

Радојчић, С. (1998). Дунавски триптих. У: Јовановић, А., Хамовић, Д. (уред.) (1998). Милосав Тешић, иесник, зборник радова. Краљево: Народна библиотека „Стефан Првовенчани“, 201-215.

Стипчевић, Н. (1998). Песма укрштених путева. У: Јовановић, А., Хамовић, Д. (уред.) (1998). Милосав Тешић, иесник, зборник радова. Краљево: Народна библиотека „Стефан Првовенчани“, 13-23.

Тешић, М. (1992). Задати облик као изазов, разговор са Милосавом Тешићем (Васа Павковић). Лейойис Майице срйске, год. 168, април 1992, књ. 449, св. 4, 711-717.

Тешић, М. (1995). Утисци и слике са границе нестајања. У: Јовановић, А. (1995). Порекло йесме-gесей разіовора о ӣоезији. Ниш: Просвета, 193-223.

Тешић, М. (2004). О устаљеним лирским облицима. Есеји и сличне раgње. Београд: Завод за уџбенике и наставна средства, 209-211.

Petrović, S. (1983). Stih. U: Škreb, Z., Stamać, A. (1983). Uvod u književnost (3. izd.). Zagreb: Grafički zavod Hrvatske, 365-428.

\section{ИЗВОРИ}

Тешић, М. (1996). Прелести севера, Круї рачански, Дунавом. Београд: Просвета.

Тешић, М. (2001). Бубњалица у йчелињаку. Чачак: Градска библиотека „Владислав Петковић Дис“. 